\title{
Krisis Ekonomi, Kesejahteraan dan Tata Pemerintahan yang Baik : Perspektif Islam
}

\author{
Winata Wira ${ }^{1,2}$, Yudhanto Satyagraha Adiputra ${ }^{3}$ \\ 1Program Studi Manajemen, Fakultas Ekonomi, \\ Universitas Maritim Raja Ali Haji, Kota Tanjungpinang, Provinsi Kepulauan Riau \\ 2 Mahasiswa Doktoral Ilmu Ekonomi, Universitas Brawijaya, Malang \\ 3Program Studi Ilmu Pemerintahan, Fakultas Ilmu Sosial dan Ilmu Politik, \\ Universitas Maritim Raja Ali Haji, Kota Tanjungpinang, Provinsi Kepulauan Riau \\ Corresponding Author: winatawira@umrah.ac.id
}

Keyword:

Perspektif Islam;

Krisis ekonomi;

Kesejahteraan;

Tata Kelola yang

Baik.

\begin{abstract}
Pelajaran dari krisis ekonomi yang berulang telah menjadi perhatian khususnya bagi dunia Islam. Sebagian besar negara Islam merupakan populasi ekonomi berpendapatan menengah dan rendah sehingga tidak terhindarkan dari kemalangan menanggung akibat buruk yang panjang dari krisis ekonomi seperti kemerosotan kesejahteraan secara drastis. Akumulasi kinerja institusi yang rendah dan kompleksnya problematika sosial ekonomi menyebabkan upaya pemulihan bukan saja berjalan stagnan namun jauh dari kriteria perbaikan-bahkan untuk mendekati level prakrisis. Dengan menggunakan perspektif Islam, tulisan ini mencoba mengeksplorasi krisis ekonomi, kesejahteraan dan harapan menuju tata kelola yang baik sebagai fundamental ketahanan di masa krisis. Dari elaborasi tinjauan literatur yang meliputi pemikiran sejumlah pakar atau pemikir ekonomi Islam serta studi empirik, negara-negara Islam sudah seharusnya mengambil determinasi dalam reformasi tata kelola yang baik karena sejalan dengan ajaran Islam untuk menjaga kesejahteran utuh berupa ad -din (agama), al-maal (harta), al-aql (intelektualitas), an-nafs (jiwa), dan an-nasl (generasi).
\end{abstract}

\section{PENDAHULUAN}

Krisis ekonomi telah menimbulkan biaya yang besar bagi ekonomi lemah. Kyrili\& Martin (2010) dariOxfam merilis laporan bagaimana negara-negara yang berpendapatan rendah mengalami apa yang disebut dengan "lubang fiskal" akibat krisis 2008-2009. Kenyataannya, negara-negara ini juga dibelenggu dengan akumulasi permasalahan sosial yang buruk sebelum krisis seperti kemiskinan dan ketidakmerataan, pangsa pekerja informal maupun kinerja sektor publik yang rendah (Djankov \& Panizza, 2020). Dengan kapasitas yang rendah untuk merespons kejutan ekonomi (Noy, Ilan. Doan, Nguyen.Ferrarini, Benno nad Park, 2020), krisis yang panjang justru mengakibatkan pelemahan semakin memburuk (Nita Madhav et al, 2017). Hal ini menunjukkan secara fudamental, ekonomi yang lemah tidak pernah siap untuk menghadapi krisis (Dornbusch, Park, \& Claessens, 2000).

Krisis berdampak terhadap kemerosotan kesejahteraan terutamanya kemiskinan dan ketidakmerataan sebagaimana dilaporkan oleh sejumlah studi (Callan, Nolan, \& Walsh, 2011; Francesco, Andrea, \& Holly, 2011; Immervoll, Peichl, \& Tatsiramos, 2011; Jenkins, Brandolini, Micklewright, \& Nolan, 2013; Matsaganis \& Leventi, 2013), termasuk penyebaran dampaknya secara empirik di sejumlah negara (Artelaris, 2017; Busch, 2010; Chang, Stuckler, Yip, \& Gunnell, 2013; Cheong, 2001; Willenbockel \& Robinson, 2009). Dampak krisis terhadap kesejahteraan juga diamati dalam seri waktu yang memadai oleh Mohseni-Cheraghlou (2016). Dari 100 pengujian terhadap krisis perbankan maupun 
mata uang di sepanjang 1981-2007, ditemukan bahwa krisis finansial dapat berdampak substansial terhadap kesejahteraan sosial dan manusia dalam bentuk peningkatan angka kejahatan, bunuh diri dan ketidakmerataan pertumbuhan dan pendapatan yang berakibat menurunnya belanja publik untuk kesejahteraan. Kontribusi Mohseni menggarisbawahi kerentanan negara dengan karakter ekonomi berpendapatan menengah dan rendah dalam mengatasi pemburukan kesejahteraan sosial dan manusia yang diakibatkan oleh krisis .

Rilis Policy Brief oleh Peneliti Senior Naudé (2009) dari Universitas PBB (United Nations University) mengungkap respon yang diperlukan untuk menghadapi krisis. Di antaranya yang sangat digarisbawahi adalah pertama, upaya responsif yang diperlukan dari dunia adalah kesadaran untuk mereformasi namun sayangnya belum menghasilkan banyak kemajuan. Kedua, bahwa negara-negara berkembang sejatinya memerlukan paradigma baru untuk pemulihan pasca krisis. Naude menggambarkan paradigma baru ini dengan narasi melepaskan diri dari ketergantungan terhadap Barat. Paradigma pemulihan krisis yang independen dari Barat terlihat sebagai agenda bersama bagi negara-negara berkembang yang memiliki karakteristik komunal. Satu dimensi perekat yang kuat diantaranya identitas keyakinan yang menjadi faktor dibalik berdirinya Organisasi Kerjasama Islam (Organization of Islamic Cooperation).

Kenyataan bahwa Islam tidak dilihat sekedar sebuah aga ma, melainkan cara hidup bagi para pemeluknya untuk mencapai kepuasan dari seluruh aspek kesejahteraan seperti sosial, politik, ekonomi maupun spiritual, maka tidak heran dunia Islam memiliki harapan kolektif yang dapat ditranslasikan menjadi tindakan bersama (Estes \& Tiliouine, 2014). Hal ini berarti sebagai cara hidup, maka dunia Islam tidak perlu terlalu melihat pada faktor-faktor yang eksogen melainkan melakukan pemeriksaan diri untuk fokus pada tanggung jawab sendiri dalam mengatasi keadaan krisis (Sidani, 2019). Tulisan ini bermaksud mengeksplorasi bagaimana krisis ekonomi, kesejahteraan dan tata kelola yang baik dapat berkaitan satu sama lain untuk menghasilkan jalan keluar dilihat dari perspektif Islam. Selain dapat memperbaharui nalar kognitif terhadap krisis ekonomi dan kesejahteraan, analisis perspektif Islam berguna dan tidak memperlihatkan resistensi, melainkan keselarasan dengan pandangan arus utama yang ada sebelumnya ketika dikaitkan dengan kepentingan reformasi tata kelola.

\section{HASIL DAN PEMBAHASAN}

\section{Krisis Ekonomi dan Agama : Tinjauan Perspektif Moral}

Moralitas belakangan semakin dikaitkan dengan kebanyakan krisis ekonomi yang berulang. Terlepas dari sifat siklikalnya, pengulangan krisis menonjolkan gagasan tentang rapuhnya sistem moral dimana pertunjukan keserakahan, kemiskinan, kelaparan dan penguasaan materil yang berlimpah kerap tidak tergantikan dari panggung utama (Moisseron \& Teulon, 2014). Kebanyakan krisis terjadi disebabkan oleh kekosongan infrastruktur moral. Seharusnya perspektif moral dapat menghasilkan analisis yang relevan dalam memahami krisis dan arah ekonomi masyarakat (Belousek, 2010; Booth, 1994; Gemici, 2013; Žitko, 2018). Salah satunya dalam bentuk sistem kepercayaan (belief) yang selama ini telah menjadi sumber spiritual ma syarakat (Hawtrey \& Johnson, 2010). Bagi Patton (2019), sistem kepercayaan bahkan dianggap satu-satunya pegangan yang dapat diandalkan untuk menghasilkan penalaran kolektif terhadap krisis.

Apabila membaca hasil riset Pew Research Center dalam The Global God Divide (2020), maka agama atau sistem kepercayaan seperti yang diungkapkan oleh Mittelstaedt (2002) dapat mempengaruhi aktivitas pasar melalui sarana politik, institusi, sosial maupun persaingan sebagaimana yang tampak pada pembangunan ekonomi dan 
integrasi ekonomi global saat ini . Dalam pembangunan ekonomi, meningkatnya kesadaran terhadap agama semakin tidak dapat dikesampingkan oleh karena sumbangan ajarannya dalam merespons kemiskinan, ketimpangan dan pelayanan terhadap masyarakat yang lebih luas (Clarke, 2016). Maka itu, sebagai satu fo ndasi moral yang ada di semua peradaban, afiliasi agama tidak akan dapat terlepas dari pembangunan ekonomi (Bowen, 2017; Jackson \& Fleischer, 2007) maupun kesejahteraan (Freud, 1961; Joshanloo \& Weijers, 2019).

\section{Perspektif Islam terhadap Krisis Ekonomi}

Perbandingan antara perspektif konvensional dan Islam diterapkan oleh Ascarya (2017) untuk memperlihatkan akar penyebab dari krisis keuangan global. Ascarya mengutip bahwa di antara faktor-faktor penyebab krisis tidak lain merupakan akibat dari perilaku atau perbuatan manusia yang melanggar hukum Tuhan, di antaranya riba, maysir (judi) dan gharar (ketidakpastian berlebihan) di banyak bidang. Dengan teknik kuantitatif yang dilakukannya, diketahui faktor penentu atau akar penyebab krisis bersifat struktural dalam hal sistem moneter, tata kelola yang buruk, sistem fiskal yang tidak berkelanjutan, dan salah laku dari para aktor ekonomi. Sebagaimana menurut elDin (2012), pelajaran yang dapat dipetik dari krisis global 2008-2009 menandakan kelemahan sistemik yang berkaitan dengan pembiayaan investasi. Menurutnya, terdapat dua permasalahan regulasi yang menjadi pemicu krisis yaitu: faktor kekuatan destabilisasi dari suku bunga dan ketimpangan antara pasar modal dan sektor -sektor produktif. Din pula menganjurkan sektor keuangan Islam dengan fitur bebas bunga dan kontrol yang lebih kuat mampu resisten terhadap motif spekulasi.

Karim (2010) menunjukkan pentingnya keuangan Islam untuk memperkuat konektivitas dengan sistem kapitalisme kesejahteraan yang lebih dulu ada. Hal ini dilatarbelakangi oleh temuannya terhadap perkembangan pesat keuangan yang patuh syariah di Malaysia, Brunei dan Kawasan MENA (Timur Tengah dan Afrika Utara). Sependapat dengan Karim, studi yang dilakukan oleh Nuhanovic \& Nurikic (2013) di Bosnia Herzegovia menunjukkan kesimpulan bahwa kegagalan kapitalisme modern dalam perangkap krisis finansial dapat dicegah melalui penerapan prinsip-prinsip ekonomi dan keuangan Islam. Nuhanovic menunjukkan bahwa perbankan Islam lebih siap untuk menghadapi berbagai jenis resiko baik operasional, likuiditas, kredit maupun pasar berbanding perbankan konvensional yang hanya menonjol dari segi resiko kredit dan likuiditas.

Perbedaan antara keuangan Islam dan konvensional merupakan permasalahan yang mendasar. Praktek konvensional dianggap menjadi penyebab kegagalan sistem keuangan yang memicu krisis, tidak lain akibat tindakan berlebihan baik pada skala rumah tangga maupun institusi keuangan yang menawarkan pembiayaan. Di satu pi hak rumah tangga melakukan peminjaman berlebihan (overborrow) sedangkan di pihak yang lain, perbankan memberikan pinjaman secara berlebihan (overlend). Hal ini yang dilihat secara negatif oleh ajaran Islam dimana hutang dari sisi permintaan adalah tidak dianjurkan kecuali untuk keperluan dasar yang sifatnya mendesak. Sedangkan dari sisi penawaran, peminjaman uang di sisi Islam harus berlandaskan pada semangat untuk menolong yang membutuhkan. Kecuali bukan untuk memperoleh keuntungan dari yang membutuhkan, keuntungan dari peminjaman di sisi Islam dibenarkan dalam kategori kerjasama usaha yang produktif dengan model bagi hasil (mudharabah) dan bukan bunga (Zakaria, Kader, Jaafar, \& Marican, 2012).

Sorotan terhadap krisis keuangan membantu reputasi kinerja perbankan Islam terutama di negara berkembang (Al-Nasser Mohammed \& Muhammed, 2017). Dilihat dari perspektif syariah dan bukan konvensional, perbankan Islam dilaporkan tidak 
terpengaruh oleh krisis keuangan. Perbankan Islam lebih aman dibandingkan konvensional, bahkan dapat mengamankan perekonomian nasional selama periode krisis. Lebih jauh, keuangan Islam dianggap sistem keuangan yang stabil dan efisien untuk mengatasi kejutan, mampu mendorong pertumbuhan dan penciptaan lapangan kerja (Derbel, Bouraoui, \& Dammak, 2011). Ulasan berbobot dari sejumlah pemikir ekonomi Islam menjadi catatan epik karena dimuat tepat pada masa dimana krisis keuangan terjadi di tahun 2008. Testimoni empat orang sejawat ekonom muslim diantaranya Muhammad Shahid Ebrahim, M. Umer Chapra, M.N. Siddiqi, dan Abbas Mirakhor didokumentasikan dengan baik dalam IIUM Journal of Economics and Management Volume 16, No.2 (2008). Masing-masing dari mereka memberikan komentar terhadap krisis keuangan, yang dengan apik dirangkum oleh Muhammed Shahid Ebrahim (University of Nottingham) dalam segmen pembahasan (1) Apa akar penyebab krisis subprima (keuangan); (2) Apa dampak krisis terhadap perekonomian global; dan (3) Apa pelajaran yang perlu dipetik oleh para ekonomi Islam dari krisis ini.

\section{Penyebab krisis subprima (keuangan)}

Krisis keuangan 2008 me nunjukkan rapuhnya sistem keuangan ribawi yang dipicu oleh ekspansi kredit dan peminjaman yang tidak cermat (Chapra\&Siddiqi). Di samping itu, bahaya moral juga terjadi akibat inovasi keuangan yang disebut dengan sekuritisasi dimana penerbitan surat utang dilakukan dengan tujuan untuk mengalihkan resiko dari mereka yang tidak mampu kepada mereka yang tidak bersedia (Chapra, Siddiqi, \& Mirakhor). Alasan lain yang mereka sepakati termasuk: (1) lingkungan regulasi yang longgar, (2) Bahaya moral sistem keuangan, (3) Perspektif keagenan atau konflik kepentingan dari para aktor heterogeni yang menyebabkan kegagalan moral.

\section{Dampak Krisis terhadap Perekonomian Global}

Krisis telah mengakibatkan kegagalan sejumlah bank sehingga menyebabkan ketidakpastian dan krisis kredit. Dampaknya, terjadi pengetatan kredit kepada perusahaan-perusahaan di industri yang lain. Krisis ini dikahwatirkan juga dapat berujung pada resesi parah yang bisa menyebabkan gagal bayar perusahaan-perusahaan di sektor riil maupun sektor keuangan ekonomi (Chapra). Krisis telah memicu kelebihan penawaran (penjualan ulang) produk perumahan sehingga menekan harga property yang bisa berdampak baik pada sektor riel maupun keuangan. Yang terjadi kemudian krisis keuangan menyebabkan kontraksi pada perekonomian global yang disebabkan oleh pengurangan perdagangan, investasi dan pengiriman uang, berdampak pada meningkatnya iklim proteksionisme. Kemerosotan nilai tukar dolar pula memberi jalan kepada krisis kembar akibat inflasi makanan dan komoditas. Penurunan nilai agunan pokok (rumah) mengakibatkan kerugian besar pada obligasi hipotek subprime (perumahan) ini, seterusnya menghancurkan basis modal institusi keuangan di seluruh dunia. Krisis kredit selanjutnya diakibatkan oleh penolakan bank untuk meminjamkan yang berujung pada pengetatan kredit terhadap sektor-sektor industri. Merebaknya kekhawatiran telah menyebabkan penurunan nilai aset di seluruh dunia, dan meningkatnya volatilitas pasar modal sehingga menganggu pertumbuhan global.

\section{Pelajaran dari Sudut Pandang Ekonomi Islam}

Inovasi keuangan dimaksudkan untuk memungkinkan kalangan yang tidak punya akses ke tangga perumahan (untuk memaksa mereka menabung, mengurangi kemiskinan dan mengakar dalam komunitas untuk tumbuh bersamanya) terbukti telah gagal (Ebrahim). Dari sisi Islam, tujuan layanan keuangan bagi masyarakat yang kurang mampu ini, identik dengan tujuan ideal yang diemban oleh para pembuat kebijakan 
Muslim yaitu: tidak cukup untuk membuat sistem keuangan yang lebih tahan kepada kejutan namun juga mengintegrasikan institusi zakah, sadaqh dan waqaf ke dalam sistem intermediasi keuangan Islam.

\section{Kesejahteraan Islam : Kualitas Hidup di Dunia dan Akhirat}

Islam mendefinisikan kesejahteraan dengan konsepsi yang integral antara material dan spiritual. Kesejahteraan menurut pandangan Islam bersifat holistik karena tujuan hidup di dunia tidak dapat dipisahkan dari kehidupan akhirat (worldly and afterlife wellbeing) (Misanam, Suseno, \& Hendrianto, 2008; Mulawarman et al., 2018). Pemeluk Islam mencapai kesejahteraan dengan mengikuti apa yang telah ditentukan di dalam Islam sebagai way of life dengan keyakinan bahwa kehidupan sebenarnya tidak berhenti karena kematian, melainkan akan berlanjut dalam sifat yang lain . Hal ini tentu kontras dengan konsepsi kesejahteraan yang diusung oleh materialisme sekuler.

Surah Al Qasas 77 berbunyi “Dan carilah pada apa yang telah dianugerahkan Allah kepadamu (kebahagiaan) negeri akhirat, dan janganlah kamu melupakan bahagianmu dari (kenikmatan) duniawi dan berbuat baiklah (kepada orang lain) menjustifikasi kesejahteraan Islam yang disebut dengan falah dalam wujud kualitas hidup dunia maupun di akhirat (Aqbar, Iskandar, \& Yunta, 2020). Falah di dunia, menurut Muhammad Akram Khan (1994) sebagaimana dikutip dari Misanam et al., (2008:3) mengandung tiga pengertian : kelangsungan hidup, kebebasan berkeinginan, serta kekuatan dan kehormatan.

\begin{tabular}{|c|c|c|}
\hline Unsur Falah & Aspek Mikro & Aspek Makro \\
\hline \multirow[t]{4}{*}{ Kelangsungan Hidup } & $\begin{array}{l}\text { - Kelangsungan Hidup } \\
\text { Biologis : Kesehatan, } \\
\text { keturunan, dsb. }\end{array}$ & $\begin{array}{l}\text { Keseimbangan } \\
\text { ekologi dan } \\
\text { lingkungan }\end{array}$ \\
\hline & $\begin{array}{l}\text { - Kelangsungan Hidup } \\
\text { Ekonomi: faktor } \\
\text { produksi }\end{array}$ & $\begin{array}{l}\text { - Pengelolaan } \\
\text { sumber daya alam } \\
\text { - Penyediaan } \\
\text { kesempatan } \\
\text { berusaha untuk } \\
\text { semua penduduk }\end{array}$ \\
\hline & $\begin{array}{l}\text { - Kelangsungan Hidup } \\
\text { Sosial : persaudaraan } \\
\text { dan harmoni hubungan } \\
\text { sosial }\end{array}$ & $\begin{array}{l}\text { - Kebersamaan } \\
\text { sosial, ketiadaan } \\
\text { konflik }\end{array}$ \\
\hline & $\begin{array}{l}\text { - Kelangsungan Hidup } \\
\text { Politik: partisipasi }\end{array}$ & $\begin{array}{l}\text { - Jati Diri dan } \\
\text { Kemandirian }\end{array}$ \\
\hline \multirow[t]{2}{*}{$\begin{array}{l}\text { Kebebasan } \\
\text { Berkeinginan }\end{array}$} & - Terbebas Kemiskinan & $\begin{array}{l}\text { - Penyediaan } \\
\text { Sumberdaya untuk } \\
\text { seluruh penduduk }\end{array}$ \\
\hline & - Kemandirian Hidup & $\begin{array}{l}\text { - Penyediaan } \\
\text { sumber daya untuk } \\
\text { generasi yang akan } \\
\text { datang }\end{array}$ \\
\hline
\end{tabular}


Krisis Ekonomi, Kesejahteraan dan. . . . . Volume 6, Issue 1, 2021

\begin{tabular}{|l|l|l|}
\hline \multicolumn{1}{|c|}{ Unsur Falah } & \multicolumn{1}{c|}{ Aspek Mikro } & \multicolumn{1}{c|}{ Aspek Makro } \\
\hline $\begin{array}{l}\text { Kekuatan dan Harga } \\
\text { Diri }\end{array}$ & $\bullet$ Harga Diri & $\begin{array}{l}\text { Kekuatan ekonomi } \\
\text { dan kebebasan dari } \\
\text { hutang }\end{array}$ \\
\cline { 2 - 3 } & $\begin{array}{l}\text { - Kemerdekaan, } \\
\text { perlindungan terhadap } \\
\text { hidup dan kehormatan }\end{array}$ & Kekuatan militer \\
\hline
\end{tabular}

Sumber: Akram Khan (1994) , sebagaimana dikutip dari Misanam et al., (2008).

Dalam ranah pengukuran, konsep kesejahteraan falah telah digunakan sebagai indikator dalam pembangunan ekonomi, sebagaimana ditunjukkan oleh Dali et. al (2015) yang mendiskusikan pemaksimuman falah sejalan dengan strategi pertumbuhan yang diinginkan oleh prinsip Islam. Kesejahteraan falah juga diteliti dalam sejumlah topik mikro yang lain seperti pengembangan kewirausahaan (Kayed, 2010; Syahpawi, 2019; Wahab, 2014), etika bisnis (Tlaiss, 2015), pembangunan dan keadilan (Abdul-Baki, 2017; Baidhawy, 2012; Sardar, 1996), manajemen dan sumber daya manusia (Abdullah, 2016; Al-Banna, 2013), serta keuangan dan perbankan (Jailani, 2020; Kalhoro, 2019).

Penjabaran falah secara empirik juga dielaborasi dalam konsep turunan yang disebut dengan maslahah atau kemanfaatan (Rasool, Yusof, \& Ali, 2020). Berdasarkan sumber Al Qur'an dan As Sunnah (contoh dari Nabi Muhammad SAW), para ulama menjabarkan penurunan maslahah terdiri atas lima aspek pokok, yaitu agama (ad-dien), jiwa (an-nafs), akal (al-aql), keturunan (an-nasl) serta harta (al-maal). Sedangkan kaedah dalam pemenuhannya tidak boleh meninggalkan atau melanggar tujuan-tujuan syariah (maqashid syari'ah).

\begin{tabular}{|c|c|c|}
\hline Dimensi Maslahah & Unsur-Unsur & Sumber \\
\hline Religiusitas (Agama) & $\begin{array}{l}\text { - Kewajiban Religius } \\
\text { - Edukasi Religius } \\
\text { - Sumbangan/ Sedekah } \\
\text { - Mencari Ilmu } \\
\text { - Aktivitas Mesjid } \\
\text { - Iman kepada Allah }\end{array}$ & 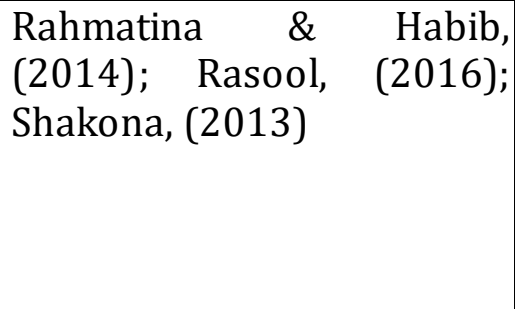 \\
\hline Intelek (Akal) & $\begin{array}{l}\text { - Level Pendidikan } \\
\text { - Program Motivasi } \\
\text { - Keahlian } \\
\text { - Partisipasi Sekolah } \\
\text { - Pengetahuan } \\
\text { - Tingkat literasi rumah } \\
\text { tangga }\end{array}$ & 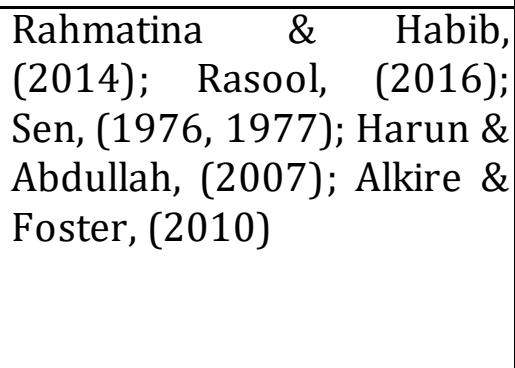 \\
\hline Ekonomi (maal) & $\begin{array}{l}\text { - Keahlian } \\
\text { - Pendapatan } \\
\text { - Daya Beli } \\
\text { - Tabungan } \\
\text { - Produktivitas } \\
\text { - Aset, Pendapatan, } \\
\text { Tanah, Ternak }\end{array}$ & $\begin{array}{l}\text { Rasool, (2016); Waggle } \\
\text { (2005, 2007, 2008); Harun } \\
\text { \& Abdullah, (2007); Che } \\
\text { Mat, et al. (2012); Abdullah, } \\
\text { Awan, } \\
\text { Aslam (2012) ; Harun \& } \\
\text { (2007); Waqas and }\end{array}$ \\
\hline
\end{tabular}


Winata Wira', Yudhanto Satyagraha Adiputra ${ }^{2}$

\begin{tabular}{|c|c|c|}
\hline Dimensi Maslahah & Unsur-Unsur & Sumber \\
\hline Keturunan & $\begin{array}{l}\text { - Masa Depan Keluarga } \\
\text { - Harmoni } \\
\text { - Aktivitas Anti-Sosial } \\
\text { - Partisipasi dalam } \\
\text { Kegiatan Masyarakat } \\
\text { - Perkawinan } \\
\text { - Anak-anak } \\
\text { - Kemerdekaan dan } \\
\text { kebebasan pribadi }\end{array}$ & 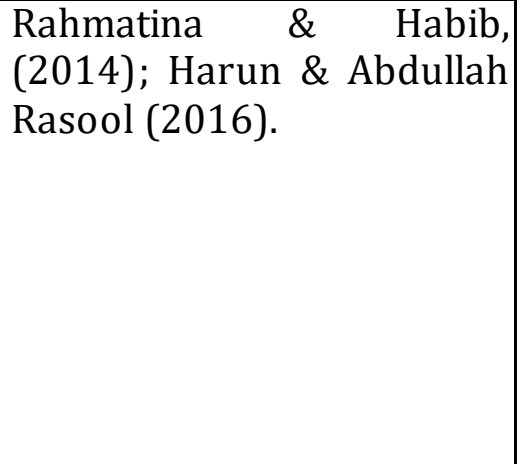 \\
\hline Jiwa (Kesehatan) & $\begin{array}{l}\text { - Konsumsi makanan } \\
\text { dan nutrisi } \\
\text { - Akses kesehatan } \\
\text { - Kesadaran kesehatan } \\
\text { - Frekuensi sakit } \\
\text { - Nutrisi } \\
\text { - Berat cairan tubuh }\end{array}$ & $\begin{array}{l}\text { Rahmatina \& Habib, (2014) } \\
\text { Che Mat et al. (2012) Fakhri } \\
\text { \& Dahlan (2015) }\end{array}$ \\
\hline
\end{tabular}

Tabel 2. Unsur-unsur Maqashid Syariah dalam Kesejahteraan Islam

Sumber : Rasool et.al, 2020, sebagaimana dikutip dari dari MD Ramli, Ghafar Ismail \& Tasrif (2015); Auda, J. (2008)

Penggunaan basis maqashid syariah secara empirik pula mendorong translasi model kesejahteraan Islam yang bersifat multi-dimensi seperti Indeks Pembangunan Keturunan (Posterity Development Index) oleh Khan, Sulaiman, \& Bahari, (2015) , Indeks Pembangunan Terpadu (Integrated Development Index) oleh Amin, Yusof, Haneef, Muhammad, \& Oziev (2015), dan pengukuran kemakmuran manusia (Shabbir, 2020). Teori Struktur Maqashid Syari'ah oleh Ulama Abad Pertengahan Imam Al Ghazali menjelaskan bahwa pemenuhan lima dimensi maslahah dilakukan melalui tiga tingkatan yaitu dharuriyyat atau wajib (primer), hajiyyat atau perbaikan (sekunder) dan tahsiniyyat atau kemewahan (tersier). Oleh karena adanya tingkat kepentingan yang berbeda-beda, Pusparini (2015) menjelaskan bahwa pemenuhan maslahah pada tiga tingkatan di atas dapat berupa, yaitu (1) Keseluruhan maslahah dilindungi dengan baik; (2) Keseluruhan maslahah dilengkapi untuk memperkuat perlindungannya; dan (3) Keseluruhan maslahah secara sederhana diperoleh secara lebih baik.

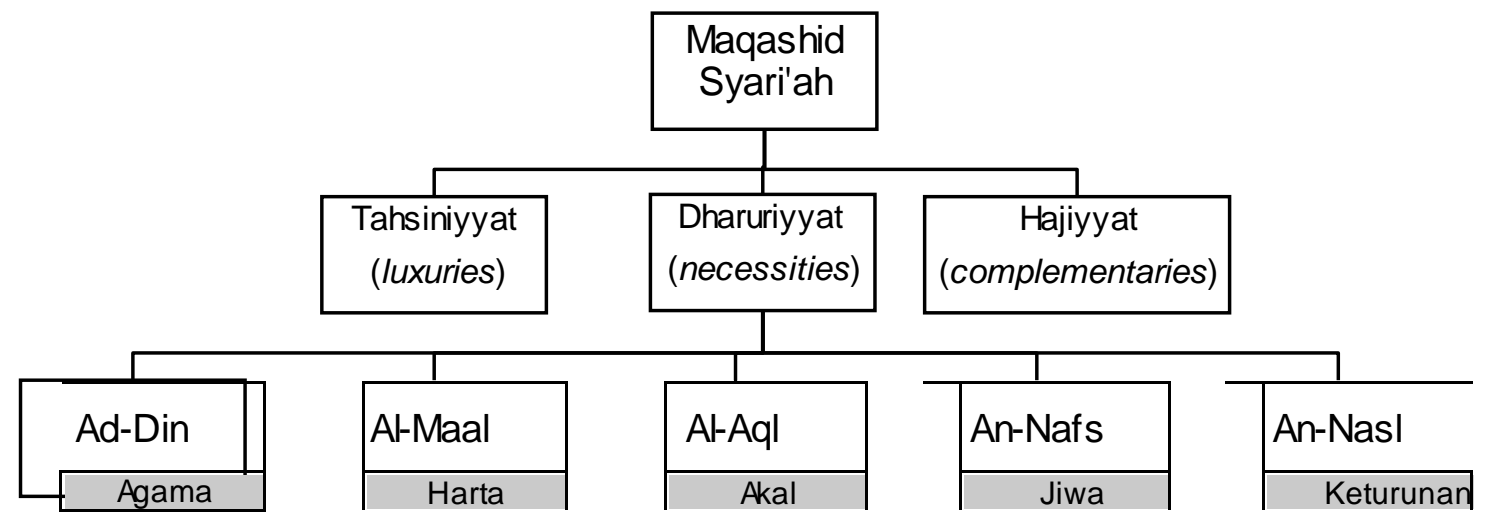

Gambar 1. Struktur Maslahah dalam Teori Maqashid Syari'ah Imam Al Ghazali.

Sumber : Rasool et.al, 2020, sebagaimana dikutip dari MD Ramli, Ghafar Ismail \& Tasrif (2015); Auda, J. (2008)

\section{Krisis dan Perubahan Kesejahteraan}


Krisis ekonomi terbukti menimbulkan dampak terhadap pelbagai sektor. Bisnis mengalami tekanan sehingga harus keluar dari industri, pengangguran bertambah, penurunan upah dan pendapatan yang drastis, pada gilirannya jumlah kemiskinan tidak terhindarkan ikut mengalami kenaikan. Besarnya beban krisis menunjukkan pentingnya bagi pemerintah untuk memperbaiki kebijakan sosial baik melalui perluasan program jaring pengaman maupun perancangan ulang skema perlindungan pendapatan (Kwon, 2001). Tekanan atas pentingnya reformasi kebijakan sosial juga dipicu dengan durasi dan tingkat kedalaman krisis yang semakin buruk sehingga menyisakan pilihan-pilihan dramatis seperti pemotongan gaji di sektor publik (Callan, Nolan, \& Walsh, 2011b).

Studi-studi mengkonfirmasi temuan tentang dampak kesejahteraan yang timbul dikarenakan terjadinya krisis ekonomi. Krisis keuangan yang disertai dengan resesi akan meninggalkan dampak negatif yang lebih besar terhadap kesejahteraan di negara -negara ekonomi berpendapatan rendah dan menengah selama periode terjadinya krisis seperti ketidaksetaraan pendapatan, keamanan, kesehatan, gizi, dan hasil pendidikan antara negara-negara kaya dan miskin. Mohseni (2016) menilai dampak krisis terhadap kemerosotan sosial dan kesejahteraan manusia lebih penting untuk diatasi dibandingkan dengan kerugian ekonomi mengingat sebagian besar dari sejumlah kerugian ekonomi justru tidak dapat dipulihkan sama sekali. Krisis terbukti telah memberikan impak terhadap memburuknya permasalahan nutrisi, ketimpangan pendapatan, kasus bunuh diri, kejahatan. Bukti yang dihasilkan dari temuan Mohseni juga memperkuat temuan dampak krisis yang dihasilkan oleh studi-studi sebelumnya.

Seperti kejahatan dan kekerasan domestik (Berk, Lenihan, \& Rossi, 1980; Mauro \& Carmeci, 2007; Moser, 1997), pendidikan anak-anak dan partisipasi angkatan kerja (Blanco \& Valdivia, 2006; Duryea, Lam, \& Levison, 2007; Rucci, 2004), masalah kesehatan dan kesehatan mental (Friedman \& Thomas, 2009; Patel \& Kleinman, 2003; Paxson \& Schady, 2005; Pohjola, 2001), ketimpangan dan kemiskinan (Baldacci, De Mello, \& Inchauste, 2002; Cheong, 2001; Galbraith \& Lu, 1999; Halac \& Schmukler, 2003), kenaikan kasus bunuh diri (Andres, 2005; Brainerd, 2001; Kirk, 2016; Minoiu \& Andres, 2008; Noh, 2009), pengangguran, harga-harga, pendapatan, ketimpangan, kemiskinan, pendidikan, kesehatan, keluarga berencana, kejahatan dan korupsi (Knowles, Pernia, \& Racelis, 1999).

Respon kebijakan dalam mengatasi dampak krisis terhadap kesejahteraan menjadi perhatian utama dari program perlindungan sosial di negara-negara. Skema jaring pengaman merupakan bagian dari program perlindungan sosial yang diluncurkan untuk mengatasi pemburukan dampak kesejahteraan di kalangan warga masyarakat secara luas. Namun pelaksanaanya mengandung perbedaan di antara negara-negara miskin dikarenakan pegeluaran belanja yang signifikan relatif terhadap PDB (Busch, 2010). Pada prinsipnya, terdapat kecenderungan alasan yang kuat untuk mendahulukan perluasan skema perlindungan sosial dalam mengatasi dampak kesejehteraan dibandingkan perhatian terhadap pertumbuhan ekonomi. Dalam kasus negara berkembang seperti Indonesia, Sumarto, Suryahadi, \& Widyanti (2005) menemukan bahwa keikutsertaan masyarakat dalam jaring pengaman sosial secara umum positif terhadap konsumsi rumah tangga namun secara spesifik program bantuan beras subsisi telah mengurangi resiko kemiskinan secara signifikan di kalangan rumah tangga yang terlibat. Jaring pengaman sosial merupakan bagian dari sistem perlindungan sosial yang telah diperkenalkan di Indonesia disebabkan meluasnya dampak sosial akibat krisis moneter.

\section{DISKUSI}

Penilaian terhadap tatanan ideal yang dibentuk dari prinsip-prinsip ajaran Islam memiliki dasar yang kuat dari sumber-sumber religius yang otoritatif seperti Al Quran 
dan As Sunnah. Pengalaman ekonomi Islam yang dominan di masa lampau turut pula membentuk pretensi tentang superioritas yang bisa dihasilkan dari keselarasan ajaran dan prakteknya yang aktual. Namun, aspirasi semacam itu kini terlihat tidak terlalu valid. Studi awal yang dilakukan oleh Rehman \& Askari (2010) mengungkap bagaimana ajaran Islam tidak menjadi praktek negara-negara Islam sebagaimana yang diperkirakan. Hal ini tercermin dari Indeks Islamisitas yang justru menempatkan negara-negara maju pada peringkat yang lebih tinggi.

Penggunaan 67 proksi dari Indeks tersebut pada kenyataannya bukanlah kontradiksi, melainkan konkordasi atau setidaknya implementasi menuju prinsipprinsip yang ditemukan di dalam ajaran Islam maupun pengalaman di masa lampau. Oleh karena itu, gambaran kegagalan sosial di sebagian besar negara Islam seperti institusi yang tidak efisien, korupsi, meluasnya kemiskinan, buta huruf, kesehatan dan ekstrimisme religius (baca: terorisme) secara tidak mengejutkan memberi pesan yang konklusif dari hasil pemeringkatan Indeks Islamisitas. Studi Estes \& Tiliouine (2014) mengamati tren pembangunan sosial di negara-negara Islam (OIC) menunjukkan variasi yang tinggi dan potret kelemahan berdasarkan Indeks Kemajuan Sosial (Social Development Index) yang disusun atas tiga aspek indikator yang utama: populasi, ekonomi dan politik. Hasilnya diambarkan bahwa negara-negara Islam masih di bawah dalam mewujudkan standar-standar yang terkait kepada variabel-variabel kemajuan sosial tersebut, meliputi:

- Dari segi populasi, pencapaian negara-negara Islam dilihat berdasarkan indikator tingkat harapan hidup, tingkat kematian bayi, tingkat literasi dewasa relatif terhadap apa yang dicapai di negara bukan Islam;

- Dari segi ekonomi, tren meningkatnya disparitas dan mel uasnya kemiskinan bahkan menjadi faktor pemicu munculnya permasalahan atau kekacauan sosial;

- Dari segi politik, masih lebih banyak negara Islam yang terperangkap dalam kegagalan sosial dan kecamuk politik seperti yang ditunjukkan oleh Indeks Kebebasan Sosial, Indeks Persepsi Korupsi, Indeks Kesetaraan Gender, dan Indeks Negara Gagal (Failed State Index).

\section{KESIMPULAN}

Pengulangan krisis ekonomi telah mempertunjukkan kegagalan tatanan finansial global yang tidak sejalan dengan prinsip-prinsip ajaran Islam. Implikasi kesejahteraan yang merosot menghadapi berbagai tantangan untuk mencapai pemulihan--bahkan pada tingkat yang relatif lebih rendah pada periode prakrisis. Namun demikian, momentum pemulihan perlu menjadi peluang strategis bagi dunia Islam untuk mengukuhkan kembali kesadaran kepada praktek-praktek yang sejalan dengan prinsip Islam (baca: maqashid syariah). Kegagalan sektor keuangan selalu tidak hanya ditanggung oleh agenagen industrial di dalam sektor tersebut, melainkan meluas kepada masyarakat di dalam perekonomian. Hal ini memberikan pelajaran bahwa keberlangsungan aktivitas yang tidak dibenarkan oleh maqashid syariah Islam pasti akan menimbulkan kerusakan yang besar dan luas. Sebagaimana praktek ribawi terbukti sebagai punca dari krisis keuangan yang berulang selama ini. Perhatikan bunyi QS Al Baqarah (279) : "Maka jika kamu tidak mengerjakan (meninggalkan sisa riba), maka ketahuilah bahwa Allah dan Rasul-Nya akan memerangimu...", maka pengingkaran terhadap hukum Allah pasti akan dibayar dengan mahal baik di dunia maupun di akhirat.

Kinerja yang lemah dalam penyelenggaran kesejahteraan di dunia Islam turut memperburuk kapasitas responsif yang diperlukan ketika berlaku kejutan (shock). Dapat dikatakan bahwa konsolidasi yang diperlukan oleh dunia Islam menuju reformasi memerlukan keseriusan dan komitmen yang kuat. Langkah-langkah yang dilakukan 
untuk memperoleh kemajuan sosial dan institusi sesuai ajaran Islam tidak seperlunya bertentangan dengan Indeks Islamisitas. Hal ini tidak lain karena implementasi tata kelola yang baik (good governance) dan perbaikan ekonomi, keuangan, politik, hukum dan sosial merupakan kaedah yang digalakkan dalam ajaran Islam sepanjang tidak bertentangan dengan tujuan syari'ah. Penting untuk dirujuk dalam hal ini, studi kualitatif Wibowo (2020) yang menunjukkan bahwa terdapat banyak kesamaan antara indikator Tata Kelola Dunia yang dikeluarkan oleh Bank Dunia dengan ajaran Islam itu sendiri.

Secara formal, Organisasi Kerjsama Islam (OIC) telah menjadikan pengamalan tata kelola yang baik sebagai tujuan bersama yang ingin dicapai oleh semua anggotanya. Hal ini sangat positif untuk mengafirmasi tindakan reformasi yang diperlukan oleh negara negara muslim untuk mencapai kualitas tata kelola pada tingkat untuk menjadi fundamental ketahanan di masa krisis. Perbaikan dimensi dan kualitas kesejahteraan sebagai hasil reformasi tata kelola harus mencerminkan perbaikan lima aspek pokok mencakup ad-Din (agama), al-maal (harta), al-aql (intelektualitas), an-nafs (jiwa), an-nasl (generasi).

\section{DAFTAR PUSTAKA}

Abdul-Baki, Z. (2017). Exploring the "social failures" of Islamic banks: a historical dialectics analysis. Journal of Islamic Accounting and Business Research, 8(3), 250 271. https://doi.org/10.1108/JIABR-06-2014-0021

Abdullah, A. (2016). Principles of Islamic management based on Surah al-Fatihah. Social Sciences (Pakistan), 11(22), 5467-5476. https://doi.org/10.3923/sscience.2016.5467.5476

Al-Banna, M. H. (2013). Islamic management system assures employee's satisfaction: Reality and future challenges. Global Journal Al-Thaqafah, 3(1), 67-84. Retrieved from https://www.scopus.com/inward/record.uri?partnerID=HzOxMe3b\&scp=84904 412788\&origin=inward

Al-Nasser Mohammed, S. A. S., \& Muhammed, D. J. (2017). Financial crisis, legal origin, economic status and multi-bank performance indicators Evidence from Islamic banks in developing countries. Journal of Applied Accounting Research, 18(2), 208-222. https://doi.org/10.1108/JAAR-07-2014-0065

Amin, R. M., Yusof, S. A., Haneef, M. A., Muhammad, M. O., \& Oziev, G. (2015). The Integrated Development Index (I-Dex): A new comprehensive approach to measuring human development. Islamic Economics: Theory, Policy and Social Justice, 2, 159-172.

Andres, A. R. (2005). Income inequality, unemployment, and suicide: a panel data analysis of 15 European countries. Applied Economics, 37(4), 439-451.

Aqbar, K., Iskandar, A., \& Yunta, A. H. D. (2020). Konsep al-Falah dalam Islam dan Implementasinya dalam Ekonomi. BUSTANUL FUQAHA: Jurnal Bidang Hukum Islam, 1(3), 516-531.

Artelaris, P. (2017). Geographies of crisis in Greece: A social well-being approach. Geoforum, 84, 59-69.

Ascarya. (2017). The real determinants of financial crisis and how to resolve it in Islamic economics perspective. International Journal of Economic Research, 14(13), 501531.

Baidhawy, Z. (2012). Distributive principles of economic justice: An Islamic perspective. Indonesian Journal of Islam and Muslim Societies, 2(2), 241-266. https://doi.org/10.18326/ijims.v2i2.241-266 
Baldacci, E., De Mello, L., \& Inchauste, G. (2002). Financial crises, poverty, and income distribution. Macroeconomic Policies and Poverty Reduction, 269.

Belousek, D.W.S. (2010). Market exchange, self-interest, and the common good: Financial crisis and moral economy. Journal of Markets \& Morality, 13(1), 83-100.

Berk, R. A., Lenihan, K. J., \& Rossi, P. H. (1980). Crime and poverty: Some experimental evidence from ex-offenders. American Sociological Review, 766-786.

Blanco, F., \& Valdivia, C. A. (2006). Child labour in Venezuela: children's vulnerability to macroeconomic shocks. Understanding Children's Work Discussion Paper.

Booth, W. J. (1994). On the Idea of the Moral Economy. American Political Science Review, 88(3), 653-667. https://doi.org/DOI: 10.2307/2944801

Bowen, J. R. (2017). Religions in practice: An approach to the anthropology of religion. Routledge.

Brainerd, E. (2001). Economic reform and mortality in the former Soviet Union: a study of the suicide epidemic in the 1990s. European Economic Review, 45(4-6), 10071019.

Busch, K. (2010). World economic crisis and the welfare state. International Policy Analysis, 1-22.

Callan, T., Nolan, B., \& Walsh, J. (2011a). The economic crisis, public sector pay and the income distribution. Research in Labor Economics (Vol. 32). Emerald. https://doi.org/10.1108/S0147-9121(2011)0000032010

Callan, T., Nolan, B., \& Walsh, J. (2011b). The economic crisis, public sector pay and the income distribution. Research in Labor Economics (Vol. 32). Emerald. https://doi.org/10.1108/S0147-9121(2011)0000032010

Chang, S.-S., Stuckler, D., Yip, P., \& Gunnell, D. (2013). Impact of 2008 global economic crisis on suicide: time trend study in 54 countries. Bmj, 347, f5239.

Cheong, K. S. (2001). Economic crisis and income inequality in Korea. Asian Economic Journal, 15(1), 39-60.

Clarke, M. (2016). Points of Equilibrium: Religious Beliefs and Economic Development Policy. Sustainable Development, 24(3), 181-189. https://doi.org/10.1002/sd.1620

Dali, M., Zohdi, M., Baharun, H., \& Ariff, T. N. A. Z. (2015). Economic Growth And Falah. Res. J. Economic and Business Studies, 4(04).

Derbel, H., Bouraoui, T., \& Dammak, N. (2011). Can Islamic finance constitute a solution to crisis. In International Journal of Economics and Finance (Vol. 3, pp. 75-83).

Djankov, S., \& Panizza, U. (2020). Developing economies after COVID -19: An introduction. In Simeon Djankov and Ugo Panizza (Ed.), Covid-19 in Developing Economies. CEPR Press. London, UK: CEPR Research.

Dornbusch, R., Park, Y. C., \& Claessens, S. (2000). Contagion: understanding how it spreads. The World Bank Research Observer, 15(2), 177-197. https://doi.org/10.1093/wbro/15.2.177

Duryea, S., Lam, D., \& Levison, D. (2007). Effects of economic shocks on children's employment and schooling in Brazil. Journal of Development Economics, 84(1), 188-214.

el-Din, S. I. T. (2012). From the great depression to the 2008 global financial crisis: Systemic flaws in investment financing. Journal of King Abdulaziz University, Islamic Economics, 25(2), 173-191. https://doi.org/10.4197/Islec.25-2.6

Estes, R. J., \& Tiliouine, H. (2014). Development Trends in Islamic Societies: From Collective Wishes to Concerted Actions. Social Indicators Research, 116(1), 67114. https://doi.org/10.1007/s11205-013-0271-5 
Fourcade, M., Steiner, P., Streeck, W., \& Woll, C. (2013). Moral categories in the financial crisis. Socio-Economic Review, 11(3), 601. https://doi.org/10.1093/ser/mwt012

Francesco, F., Andrea, S., \& Holly, S. (2011). Economic Downturn and Stress Testing European Welfare Systems. In H. Immervoll, A. Peichl, \& K. Tatsiramos (Eds.), Who Loses in the Downturn? Economic Crisis, Employment and Income Distribution (Vol. 32, pp. 257-286). Emerald Group Publishing Limited. https://doi.org/10.1108/S0147-9121(2011)0000032012

Freud, S. (1961). The future of an illusion.(J. Strachey, Trans.) New York. NY: WW Norton \& Company.

Friedman, J., \& Thomas, D. (2009). Psychological health before, during, and after an economic crisis: Results from Indonesia, 1993-2000. The World Bank Economic Review, 23(1), 57-76.

Galbraith, J. K., \& Lu, J. (1999). Inequality and financial crises: Some early findings. Inequality and Industrial Change: A Global View.

Gemici, K. (2013). Moral economy redux: Social protests in Turkey after the 2001 economic crisis. In Mobilization (Vol. 18, pp. 143-160). https://doi.org/10.17813/maiq.18.2.y530w66u36526878

Halac, M., \& Schmukler, S. L. (2003). Distributional effects of crises: the role of financial transfers (Vol. 3173). World Bank Publications.

Hamdi, B. (2017). Maslahah Dalam Paradigma Tokoh (antara Al-Ghazali, As Syatibi dan Najmuddin Al Thufi). Al Hurriyah: Jurnal Hukum Islam, 02(02).

Hawtrey, K., \& Johnson, R. (2010). On the Atrophy of Moral Reasoning in the Global Financial Crisis. In Journal of Religion and Business Ethics (Vol. 1, p. 4).

Immervoll, H., Peichl, A., \& Tatsiramos, K. (2011). Who Loses in the Downturn? Economic Crisis, Employment and Income Distribution (Research in Labor Economics, Volume 32). Emerald Group Publishing Limited.

Jackson, P., \& Fleischer, C. (2007). Religion and economics: a literature review. RAD Working Papers Series. from http://epapers.bham.ac.uk/1504/1/JacksonandFleischer-

_Religion_and_Economics.pdf

Jailani, N. (2020). Decision model and simulation for autonomous lenient bidding in Shariah-based e-auction. Malaysian Journal of Consumer and Family Economics, 24, 156-174. Retrieved from https://www.scopus.com/inward/record.uri?partnerID=HzOxMe3b\&scp=85094 679884\&origin=inward

Jenkins, S. P., Brandolini, A., Micklewright, J., \& Nolan, B. (2013). The Great Recession and the Distribution of Household Income. Oxford University Press. https://doi.org/10.1017/CB09781107415324.004

Joshanloo, M., \& Weijers, D. (2019). Islamic Perspectives on Wellbeing. In L. Lambert \& N. Pasha-Zaidi (Eds.), Positive Psychology in the Middle East/North ... (pp. 237-256). Springer. https://doi.org/10.1007/978-3-030-13921-6_11

Kalhoro, M. (2019). Customer satisfaction in commercial bank of Sindh pr ovince a case study of bank Al Falah. Library Philosophy and Practice, 2019. Retrieved from https://www.scopus.com/inward/record.uri?partnerID=HzOxMe3b\&scp=85066 109732\&origin=inward

Karim, W. J. (2010). The economic crisis, capitalism and Islam: The making of a new economic order? Globalizations, 7(1-2), 105-125. https://doi.org/10.1080/14747731003593315 
Kayed, R. (2010). Islamic entrepreneurship: A case study of Saudi Arabia. Journal of Developmental Entrepreneurship, 379-413. https://doi.org/10.1142/S1084946710001634

Khan, Z., Sulaiman, J., \& Bahari, Z. (2015). Socioeconomic human well -being and posterity: a newly proposed faith-based measurement index. Journal of Religion \& Spirituality in Social Work: Social Thought, 34(1), 72-90.

Kirk, R. (2016). Drugs, Thugs, and Diplomats: US Policymaking in Colombia by Winifred Tate. Anthropological Quarterly (Vol. 89). https://doi.org/10.1353/anq.2016.0080

Knowles, J. C., Pernia, E. M., \& Racelis, M. (1999). Social consequences of the financial crisis in Asia: the deeper crisis.

Kwon, S. (2001). Economic crisis and social policy reform in Korea. International Journal of Social Welfare, 10(2), 97-106. https://doi.org/10.1111/1468-2397.00159

Kyrili, K., \& Martin, M. (2010). The impact of the global economic crisis on the budgets of low-income countries. In Oxfam International. Citeseer.

Matsaganis, M., \& Leventi, C. (2013). The distributional impact of the Greek crisis in 2010. Fiscal Studies, 34(1), 83-108.

Mauro, L., \& Carmeci, G. (2007). A poverty trap of crime and unemployment. Review of Development Economics, 11(3), 450-462.

Minoiu, C., \& Andres, A. R. (2008). The effect of public spending on suicide: evidence from US state data. The Journal of Socio-Economics, 37(1), 237-261.

Misanam, M., Suseno, P., \& Hendrianto, M. B. (2008). Ekonomi Islam. Pusat Pengkajian dan Pengembangan Ekonomi Islam (P3EI) UII Yogyakarta dan Bank Indonesia. Raja Grafindo Persada.

Mittelstaedt, J. D. (2002). A framework for understanding the relationships between religions and markets. Journal of Macromarketing, 22(1), 6-18. https://doi.org/10.1177/027467022001002

Mohseni-Cheraghlou, A. (2016). The Aftermath of Financial Crises: A Look on Human and Social Wellbeing. World Development, 87, 88-106. https://doi.org/10.1016/j.worlddev.2016.06.001

Moisseron, J.-Y., \& Teulon, F. (2014). Is Morality-Based Islamic Economics an Answer to the Global Financial Crisis? by: Jean-Yves Moisseron, comment. Journal of King Abdulaziz University: Islamic Economics, 27(1), 125-138.

Moser, C. (1997). Household responses to poverty and vulnerability. Vol. 1, confronting crisis in Cisne Dos, Guayaquil, Ecuador. The World Bank.

Mulawarman, A. D., Manzilati, A., Djalaluddin, A., Kamayanti, A., Herlambang, L., Triyuwono, I., ... Abdurahim, A. (2018). Kesejahteraan Semesta (Pertama). Jakarta Selatan: Yayasan Rumah Peneleh.

Naudé, W. (2009). The Global Economic Crisis After One Year. UNU Policy Brief, 02(2), 18.

Nita Madhav et al. (2017). Pandemics: Risks, Impacts, and Mitigation. In Disease Control Priorities, Third Edition (Volume 9): Improving Health and Reducing Poverty (pp. 315-345). The World Bank. https://doi.org/doi:10.1596/978-1-4648-05271_ch17

Noh, Y.-H. (2009). Does unemployment increase suicide rates? The OECD panel evidence. Journal of Economic Psychology, 30(4), 575-582.

Noy, Ilan. Doan, Nguyen.Ferrarini, Benno nad Park, D. (2020). The Economic Risk of Covid-19 in developing countries: Where is it highest? In U. Panizza \& S. Djankov (Ed.), Covid-19 in Developing Economies. CEPR Press. London, UK: CEPR Research. 
Nuhanovic, A., \& Nurikic, M. B. (2013). A conceptual view of ethical aspect of financial crisis: Case of B \& H (Islamic) banking sector. Banks and Bank Systems, 8(3), 41 54.

Patel, V., \& Kleinman, A. (2003). Poverty and common mental disorders in developing countries. Bulletin of the World Health Organization, 81, 609-615.

Patton, E. (2019). Of Vice and Virtue: Religious and Moral Rhetoric in the Business Press and the Economic Crisis. In Journal of Religion and Business Ethics (Vol. 4, p. 5).

Paxson, C., \& Schady, N. (2005). Child health and economic crisis in Peru. The World Bank Economic Review, 19(2), 203-223.

Pohjola, A. (2001). Health problems and long-term unemployment. Social Work in Health Care, 34(1-2), 101-112.

Presbitero, A. F., \& Zazzaro, A. (2013). The global crisis in low- and middle-income countries: How the IMF responded. The Global Economic Crisis: New Perspectives on the Critique of Economic Theory and Policy, 144, 217-245. https://doi.org/10.4324/9780203816721

Pusparini, M. D. (2015). Konsep Kesejahteraan Dalam Ekonomi Islam (Perspektif Maqasid Asy-Syari'ah). Islamic Economics Journal, 1(1), 45. https://doi.org/10.21111/iej.v1i1.344

Rasool, M. S. A., Yusof, M. A. M., \& Ali, S. M. (2020). Wellbeing of the society: A Maqāşid Alsharīah approach. Afkar, 2020(Special Issue 1), 25-46. https://doi.org/10.22452/afkar.sp2020no1.2

Rehman, S. S., \& Askari, H. (2010). How islamic are islamic countries? Global Economy Journal, 10(2). https://doi.org/10.2202/1524-5861.1614

Rucci, G. (2004). Macro Shocks and Schooling Decisions: The Case of Argentina.|| UCLA Working Paper Series. Los Angeles: University of California at Los Angeles.

Sardar, Z. (1996). Beyond development: An Islamic perspective. European Journal of Development Research, 8(2), 36-55. https://doi.org/10.1080/09578819608426664

Shabbir, M. S. (2020). Human Prosperity Measurement within The Gloom of Maqasid AlShariah. Global Review of Islamic Economics and Business, 7(2), 105-111.

Sidani, Y. (2019). Does Islam impede development? A critical analysis. Journal of Islamic Accounting and Business Research, 10(5), 644-662. https://doi.org/10.1108/JIABR-06-2017-0092

Sumarto, S., Suryahadi, A., \& Widyanti, W. (2005). Assessing the impact of Indonesian social safety net programmes on household welfare and poverty dynamics. European Journal of Development Research, 17(1), 155-177. https://doi.org/10.1080/09578810500066746

Syahpawi. (2019). Syirkah Amlak's implications in building community economic independence (analysis of Meranti islands regency, Riau province). International Journal of Innovative Technology and Exploring Engineering, 8(9), 1569-1575. https://doi.org/10.35940/ijitee.I3328.0789S319

Tlaiss, H. A. (2015). How Islamic Business Ethics Impact Women Entrepreneurs: Insights from Four Arab Middle Eastern Countries. Journal of Business Ethics, 129(4), 859877. https://doi.org/10.1007/s10551-014-2138-3

Wahab, K. A. (2014). Measuring small firm entrepreneur's performance based on AlFalah. World Applied Sciences Journal, 29(12), 1532-1539. https://doi.org/10.5829/idosi.wasj.2014.29.12.2058

Wibowo, M. G. (2020). Good Public Governance in Islamic Perspective: An Analysis on the World Governance Indicator in OIC Member Countries. Ihtifaz: Journal of Islamic 
$\begin{array}{llll}\text { Economics, } \quad \text { Finance, } & \text { and }\end{array}$ https://doi.org/10.12928/ijiefb.v3i1.1718

Willenbockel, D., \& Robinson, S. (2009). The global financial crisis, LDC exports and welfare: analysis with a world trade model.

Zakaria, R. H., Kader, R. A., Jaafar, N. I. M., \& Marican, S. (2012). Burgeoning household debt: An islamic economic perspective. Middle East Journal of Scientific Research, 12(9), 1182-1189. https://doi.org/10.5829/idosi.mejsr.2012.12.9.267

Žitko, M. (2018). Governmentality verus moral economy: notes on the debt crisis. Innovation: The European Journal of Social Science Research, 31(1), 68-82. 